\title{
German Water Infrastructure in China: Colonial Qingdao 1898-1914
}

\author{
Agnes Kneitz
}

Deutsche Wasserinfrastruktur in China: Das koloniale Qingdao 1898-1914

Im bunten Flickenteppich der überseeischen Besitzungen, die das Deutsche Reich während seiner kurzen Lebenszeit zusammenfügte, sticht das deutsch-chinesische Qingdao heraus, da es im Vergleich zu den Besitzungen in Afrika eine andere Funktion erfüllte - vor allem aufgrund seiner modellhaft angelegten Wasserinfrastruktur. Das Reichsmarineamt, dem die Verwaltung der zukünftigen „Hafenkolonie” - zunächst kaum mehr als ein Fischerdorf - oblag, hatte bei der Implementierung dieses Vorhabens ein bemerkenswertes Maß an Freiheit. Die deutsche Regierung investierte zudem enorme Summen, um China und der Welt seine technokulturellen Errungenschaften vorzuführen. Dabei griff man massiv auf die natürlichen Ressourcen des bergigen Hinterlandes zurück. Dieser Beitrag fokussiert auf die Wasserinfrastruktur von Qingdao sowie deren Rolle für die öffentliche Gesundheit und weitere Erschließung des Großraumes. Dabei werden nicht nur Ambivalenzen der Wasserinfrastruktur als "tool of empire" an Hand von empirischem Material aufgezeigt. Vor allem geht der Beitrag - in Anlehnung an das Konzept des "urbanen Metabolismus” - ihren ökologischen Auswirkungen nach, speziell der landschaftlichen Transformation der umliegenden Berge sowie ihre Folgen für den Wasserhaushalt der Region. Es wird dabei die These vertreten, dass ökologische Veränderungen eine wesentlich größere Rolle bei der Bewertung kolonialer Unternehmungen spielen sollten.

Schlüsse/wörter: China, Deutsches Kaiserreich, Infrastruktur, Wasser, Forstwesen

Within the colorful tapestry of colonial possessions the German empire acquired over the short period of its existence, Qingdao stands out because it fulfilled a different role from settlements in Africa-especially because of its exemplary planned water infrastructure: its technological model, the resulting (public) hygiene, and the adjunct brewery. The National Naval Office (Reichsmarineamt), which oversaw the administration of the future "harbour colony" - at first little more than a little fishing village-enjoyed a remarkable degree of freedom in implementing this project. The German government invested heavily in showing off its techno-cultural achievements to China and the world and thereby massively exploited the natural resources of the mountainous interior. This contribution focuses on Qingdao's water infrastructure and its role in public hygiene and further area development. This article will not only use new empirical evidence to demonstrate that the water infrastructure was an ambivalent "tool of empire". Relying on the concept of "urban metabolism," this paper primarily traces the ecological consequences, particularly the landscape transformation of the mountains surrounding the bay and the implications for the region's water resources. When evaluating colonial enterprises, changes in local ecology should play a significantly greater role. 


\section{Scouting-The Overseas Territory}

When the German colonial administration initiated urban development in Qingdao (青我) in 1898, China had just adopted a discourse on public health and Western medicine for its reform efforts (Rogaski 2004). Influenced by everyday encounters with foreign practices in the international concessions all over China, this would eventually result in a "sanitized modernity" similar to what has been described for other parts of Asia (Arnold 2013: 126). Among the Western settlements that had been forced onto the Qing Empire, Qingdao stands out. The city was designed so as to demonstrate the German empire's technological superiority, ultimately turning its infrastructure into an export good for the Chinese market that the Western forces aspired to penetrate. It aimed at providing solutions for "bacteriological cities" (Gandy 2004: 365), and although the Qing Empire was at most only semi-colonized, ${ }^{1}$ infrastructure thus became an everyday "tool of empire." Gift-wrapped as a commodity, it was presented with complimentary customized technological and sanitary values (Reddy 1976 cited after van Laak 2004: 42).

Water pipes, canals, and drainage provide a city's invisible supportive network. In this basic function they also directed historical Qingdao's material flows, and connected the town ecologically to its hinterland in a way that makes it impossible to tell either story without the other (Cronon 1992). Therefore, the article evokes to the concept of "urban metabolism" as a metaphor to address the changes Qingdao inflicted on the local landscape. ${ }^{2}$ This allows to describe social and bio-physical interactions in and between different systems in all their complexity (Gandy 2004). I am interested in how differences in regional urban material and energy flows-which become apparent when comparing European and Asian style cities (Weber 2012: 33) - may have been affected by transplanting Western infrastructures into Asian environments. A classical "tool of empire" by nature (Headrick 1981), Qingdao's sophisticated water infrastructure was designed as a purchasable and replicable foundation for human well-being. Its creators aspired to establish a technical role-model ameliorating everyday life in the crumbling Qing Empire (Scott 1998: 4): technology had become an intrinsic part of Germany's "cultural mission". But silently and almost invisibly, this infrastructure also segregated the city along lines of class and race, leading to echeloned standards of public hygiene.

This particular intersection between environmental and social history is an important path upon which German imperialist expansion needs to be revisited to assess its role within the current framework of global historical approaches (Conrad 2013). Previous research on Qingdao has already investigated related structural issues such as the role of railroad 
politics for areal development (Schmidt 1979) or the importance of land tenure as a tool for governance (Matzat 1985). Other studies have applied a dependency-orientated approach when investigating its role in the Kaiserreich's colonial politics (Albertini 1982; Naumann-Schultz 1985). The city's unique status as a "model colony", however, was not addressed until 1994 (Leutner 1994). The centennial sparked a new wave of literature on Qingdao, including an edited volume by the German Historical $\mathrm{Mu}$ seum in Berlin that addresses Qingdao's distinct politics against its Chinese historical background (Hinz 1998), as well as several dissertations. These have brought forward the idea of a distinct German-Chinese colonial architectural style (Lind 1998) or highlighted the impact of foreign rule on Chinese cultural change through the perspective of Qingdao's institutions (Biener 2001). Among these, Torsten Warner's PhD dissertation is of particular importance (Warner 1996) which investigates Qingdao's planning and development in relation to other foreign settlements with a focus on reciprocal effects sparked by cultural exchange. This book has become a standard work in Chinese, initiating more follow-up studies, for example on Qingdao's "hut villages" that remain hot spots of development to this very day (Zhan 2002). Recent studies approach social, cultural and everyday history in Qingdao, including racial problems, cultural differences, or gender issues (Leutner 2009), but also jurisdiction and civil administration (Mühlhahn 2000), economic politics and trade (Herold 2006), or new approaches to colonial politics (Mühlhahn 2013), as well as a study about Qingdao's hospitals and their development under different governments (Vögele 2015).

None of these studies, however, focuses on environmental history or systematically discusses human-environmental relations. Taking up this challenge, my paper incorporates nature as a common denominator in a study on culture and place in the broadest sense (Ferguson 1997). Water infrastructure makes an interesting study object through its practical function that distinctly connects humans with their environment by supporting their most important and intimate bodily functions. The most promising sources to address Qingdao's infrastructural development are the government's annual reports, covering the fiscal years from October 1898 to September 1914. These were used to communicate with the political and economic stakeholders at home. Their composition allows interpretations regarding the importance of different topics in the colonialist's day-to-day operations as well as the overall colonial project. The annual reports are part of the colonial government's official records that are kept by the German Federal Military Archive in Freiburg. Some of these papers are also held in copy by the Qingdao Municipal Archives, featuring individual episodes of development, such as the water system's construc- 
tion management. In contrast to these German resources that also have been employed for the previous studies on Qingdao, so far no significant Chinese-language accounts of the city's founding years could be identified. Admittedly, this imbalance of written sources calls for a clarification of the paper's potentials and limits. While it does not allow for first-hand accounts of perceptions and attitudes towards Qingdao's water infrastructure of the local Chinese population, the German corpus offers rich material to analyze the city-nature relationship. This paper is part of a larger book project, which will supplement the accounts of the occupying forces with a survey of foreign language newspapers as well as social and technical documents. What is striking about the documents from the German colonial administration is an intense focus on-almost an obsession with-hygiene and the promises of water engineering and forest management, they grant far-reaching insights into the landscape changes induced by the city and its development.

This is the point of departure of this paper: it provides a detailed account of the measures the German colonizers took in building a new, "hygienic" settlement from scratch, as well as the environmental responses to and effects of this ambitious attempt of urban development. It furthermore outlines the geographical and social conditions that imprinted the scope for engineering and urban planning. Focusing in particular on the social and environmental relations/sides of infrastructure development, it then traces the implementation of a water infrastructure that was originally designed for a European context in its specific local colonial form and setting in colonial China. In the last chapter, the paper extends the perspective to Qingdao's hinterland, highlighting non-human, non-technological actors and their influence on engineering and urban planning.

Infrastructures are a crucial link between nature and human civilization; colonial rule and everyday life; rich and poor; as well as state and economy, and certainly belong to the most powerful institutions in recent human history. As part of colonial development projects, they compellingly signify continuous (re)negotiation of space and natural resources by human and non-human actors alike (Ertsen 2016: 215). Once implemented, however, they are taken for granted, and thus prone to oblivion-including historical research (van Laak 2004: $10 \mathrm{f}$.). In some cases, this may be attributed to their actual existence under ground. Bearing in mind that political history can never be detached from ecological history, this paper investigates government's actions to create a modern technological model within an environment that has not always been supportive in social, political, and natural matters. In this case, Qingdao's from scratch development vividly illustrates how colonial forestry and water politics were ecologically entwined and interdependent. Hence, in this paper I am going to sketch the 
construction of Qingdao's water infrastructure as related to geographical predispositions, introducing its stakeholders and limits. Rather than foregrounding the system's physical materiality, it reflects on tensions between topography and city design, technology and society, especially public health and equality. The paper also introduces another set of non-human actors into this story on environmental changes by technology: trees, which almost formed a symbiotic relationship with the infrastructure. Together, this "envirotechnical system" (Pritchard \& Zeller 2010) profoundly impacted on Qingdao's local economy and ecology, changing the area's overall development way beyond the Germans' departure. By bringing together the topics of infrastructure, colonialism, and environment, the article highlights the vital importance of analyzing changes in local environments, especially the water regime that followed the transfer of infrastructure from the Europe to the colonial world.

\section{Mapping-The Area's Geography}

Starting in 1868, an expedition led by Ferdinand von Richthofen had scouted the coasts of the Yellow Sea for the European-American Chamber of Trade, which would later allow him to identify Qingdao as a potential base and strategic ice-free harbor for the German navy in China (Richthofen 1897: 14 f.). Ironically, Chinese reformers had considered the very same location in the Jiaozhou (胶州) Bay as a possible fortification against Western intervention in 1897 (ibid.: $100 \mathrm{f}$.), yet the dying Qing Empire's increasing instability, which would fall within the next decade, averted their attention. That very same year, Admiral von Tirpitz pressed forward a naval bill promoting quick decision-making (Herold 2006: $38 \mathrm{f}$.), thus allowing Germany's annexation of a small tip of the Shandong (山东) peninsula following a Chinese assault on the Divine Word (aka Steyler) Missionaries in the area. ${ }^{3}$ The occupation was hastily legalized by a lease. At that time, development plans, including land development, harbor construction, outline of water pipes and streets, or afforestation, had already been finalized; its hydrological capacity and functionality been assessed. ${ }^{4}$

Like all of Southwest China, the Shandong peninsula is influenced by the East-Asian monsoons. During summer, southerly winds from the sea bring warmth and humidity, whereas winter is defined by cold and dry continental ones. Historical temperatures range between zero degrees Celsius in January and 25 degrees in August, and were considered as mild in comparison to the Chinese mainland. Humidity, however, varied greatly (between 30 and 100 per cent). Qingdao's climate was thus often perceived as 
uncomfortable despite almost tropical summers with relatively little wind, and warm temperatures. A mediating factor for weather and climate are the surrounding mountains, namely the western foothills of Laoshan (崂山), that also marked the boundaries for the city's outline (Eckart 1997: 460). The so-called "Pearl Mountains" line up along the coast and divide the area naturally into smaller sections. They provided the prospective city territory with a natural watershed that would later help to mitigate miasmabased European "environmental anxieties" concerning harmful influences of alien germs and environments on the Caucasian body (Beattie 2011).

Germany's 1920 colonial encyclopedia nostalgically depicts Shandong's mountains rising out of the North-China plains like an island. Thin sedimentary layers contrasted a coherent mountain range of mostly old sediments like basalt and granite (Wang et al. 2011). Coarse-grained, porous, and fissured topsoil had bad filtering qualities, subsequently making the hard-based peaks prone to erosion, looking rugged. Only few plants would find enough hold, and during the seasonal rainfalls large amounts of soil flowed through the mountains' dried-out riverbeds. Within their sediments-often compared to the Southern Alps in Italy-water trickled away quickly, keeping them dry except for one or two days after heavy weather (Schnee 1920). But to the annoyance of the engineers, even light rain would occasionally turn creeks into torrential waters that regularly scoured the colony's railway paths (Mühlhahn 1998: 151). As in other colonial enterprises, warnings by the native inhabitants to pay attention to the area's natural history had been generally ignored for the sake of cheaper bridgebuilding. Yet this ignorance of local knowledge eventually resulted in doubled or tripled costs due to repair and reconstruction works.

With few proper rivers in the area, most waters fed subterraneanously into the ocean, and water supply depended on wells. Over the centuries, their tapping had become sophisticated enough to support agriculture, and horticulture in particular (Stenz 1902: 7). Hence, the lush orchards of local peasants indicated to foreign developers that forestry was a profitable enterprise. It further seemed to suggest that the bare mountain backs were a result of Chinese mismanagement, which resonated with a degenerated infrastructure of an economically idle area devoid of industry that had fallen prey to tax-hungry authorities (Stenz 1902: 8). Based on contemporary knowledge of soil properties, trees were subsequently planted in the Jiaozhou Bay hills to increase the general moisture level. Moreover the trees had the welcome side effect of additional economic value in promoting the protectorate's self-sufficiency-while actually and primarily responding to German aesthetic and nostalgic needs. ${ }^{6}$ But they also held a variety of unintended ecological consequences. 
The spatially open design of Qingdao's defense lines, caused by a mountainous geography (Zhan 2002: 53), is one aspect in which it varied significantly from other colonial and Chinese cities, and one that supports categorizing it as a frontier city. The volition to shape it as a completely new model city was quite exceptional, though such an enterprise was admittedly seldom feasible or sensible in other locations (Osterhammel 2009: 284). And as a matter of fact, Kiaochow Bay would become an enormous financial stress factor for the German treasury, provoking heated parliamentary debates during its short existence. With 13,260 million Reichsmark in $1902^{7}$ expenses were so high that the sheer amount explains the significant difference in development compared to other German colonies (Warner 1996: 85); local taxes only contributed 300,000 Reichsmark. But the German Emperor had decided that his country's future lay waterborne, and his glorified navy as the governing body seems to have mitigated Qingdao's perception as a deterrent example. Within an average annual budget of its early settlement years, about 2,755 million Reichsmark went into developing infrastructure. The water supply system and related underground engineering consumed the lion's share of this, including costs for human resources. After 1908, with the opening of a large-scale centralized waterworks, costs gradually decreased as its maintenance costs only amounted to 300,000 Reichsmark. ${ }^{8}$

\section{Designing-The Project Landscape}

The "colonial city" as such was a typical contemporary form usually represented in South East Asia in the shape of a port. Different blends of European and non-European styles in urban structure and construction followed imperial expansion, with a trade harbor at the settlement's heart. Thus it is easy to follow the architectural traces of Europe around the globe (Osterhammel 2009: 283). In this respect Qingdao did not differ much from other outposts, but given its unique possibility to invent itself, it could take liberties in building style that almost developed into a "German-Chinese-Overseas-Style," as the close inspection of its historical buildings suggests (Lind 1998). As in other foreign settlements, these stylistically mixed forms were often strategically used to express cultural openness (Warner 1996: 60).

Within the framework of Europe's self-proclaimed civilizing mission in Asia, Germany envisaged the Qingdao "model colony" as a life-size object of study for reform-willing locals. The infrastructural development plan connected the city with its overseas harbor to coal mines and po- 
tential trading partners in the hinterland; projected to eventually feed into China's inland trade routes. ${ }^{9}$ For that purpose, an infrastructural network was established that consisted of water and sewage treatment, gas and electricity supply, agriculture, forestry, and mining, as well as roads and railroads to aggregate resources in the bay area. The latter second-handedly placed massive pressure on the surrounding environment in a way that is typical for quickly urbanized cities (Cronon 1992). Given their strategic economic importance, developing the Shandong Mining and Shandong Railway Associations (which were financed by corporate shareholders) had priority. ${ }^{10}$ Industrial growth, however, was limited to small and mid-size companies with often bi-national capital basis, as no large private enterprises/entrepreneurs invested in Qingdao.

The colony's economic progress and general development are mirrored in the increasing fragmentation of the government's annual reports. The documents' basic structure remains unchanged but supplements individual chapters on education and science (including meteorological observation), water supply, farming, and forestry. Here the administrators' educational background shines through, who valued forestry as an integral part of the cameral sciences (Beattie 2011: 125). The 1899 memorandum, for example, reports on water supply and afforestation together, emphasizing the relationship between forest cover and hydrologic balance. ${ }^{11}$ Scientific knowledge often informed infrastructural planning (Bennett \& Hodge 2011). As James Beattie has laid out for South Asia, German-style forestry as a state administered applied science often translated directly into colonial politics (Beattie 2011: 125). A firm belief in water engineering, scientific forestry, and landscape management had become second nature to the Germans by the end of the nineteenth century, both in the Kaiserreich as well as overseas (Blackbourn 2006: 8).

In "an age dominated by agricultural values," so Donald Worster, "turning land to productive use was an unquestioned cultural imperative" (1986: 73). After having mastered the Rhine, turning the unfamiliar, bare Chinese landscape into a forested green jewel epitomizes a peak of engineering optimism without comparison to any other German territory. This might be related to the naval officers' enthusiasm in developing their port. But similar to the arid West of the United States of America where "coordinated triumph over scarcity through technology" (ibid.) lay at the core of progress, German engineering had turned technology into culture, and perceived water works as "culture works" in its self-assigned imperialist mission (Blackbourn 2006: 194). By the end of the century, infrastructure had evolved into a political parameter that was measured in assets such as transportation costs. Macroeconomic theory had reduced its intrinsic value to only one of many location factors (van Laak 2004: 29). 
Immediately after seizing the bay, Qingdao's construction as a military post began on the site of an old fishing village. Similar to Rio de Janeiro or Cape Town, both "early modern innovation in previously non urban settings," it can be classified as "frontier city" (Osterhammel 2009: 288). In his travel accounts, Ferdinand von Richthofen evoked similar images (Leutner 1997: 58). The city's development as a whole designated non-white, nonEuropean residents to participate only as subordinates, or even instruments of conquest. Here, water infrastructure became an invisible dual system and contributed to the so-called "rule of difference" in governance that George Steinmetz finds applied in Qingdao despite its semi-colonized state (Steinmetz 2007: 37). And with it, sanitary practices derived from contemporary European discourse (Allen-Emmerson et al. 2012) never ran dry as a source of cultural clashes. Almost every foreign visitor mentioned such (i.e. Penck 1911; Tirpitz 1919), which eventually contributed to sparking a Chinese discourse on public hygiene (Rogaski 2004: 18). For Qingdao, these discussions became fundamental to its overall development plan, yet resulting in spatial segregation (Mühlhahn 2013: 113).

Like for any other place chosen as a strategic node, water infrastructure was vital for Qingdao: its 1899 annual report refers to the water system as the city's most important feature, especially concerning the colonial body's public health. ${ }^{12}$ Health and public hygiene had proven to be sore spots in all foreign settlements in China. Now Germany saw its opportunity to rise and shine. In engineering affine circles, technology had become identical with culture (Blackbourn 2006). The wife to an envoy in Beijing predicted that soon the Chinese would prefer the comfort deriving from modern Western technology in an European-style city to that of their own (Leutner 2009: 59). In general, the military was trained and experienced in designing infrastructure for strategic reasons: as tools for imperial governance. German colonialists thus held the belief that Qingdao's water system would turn out more sophisticated and durable than one constructed by civil engineers. Due to the German navy's strict hierarchical and centrally managed internal organization, an on-base execution was moreover expected to be more structured and efficient.

Since the 1860s, in the aftermath of the traumatic experiences such as the Opium Wars or the Taiping Rebellion, the Prussian military had supported China in advancing its military to Western standards. ${ }^{13}$ Its resulting reputation possibly added value and credibility to Qingdao as an enterprise and model project. By deploying the navy the German Kaiserreich thus acted as an entrepreneur, financing the entire infrastructure as future investment (van Laak 2004: 33). Although railroads were part of this enterprise, Qingdao's case differed significantly from the "railway imperialism" that relied heavily on natural resource extraction (Robinson 1991: 3). 
It seems that compared to Africa, technology itself was seen as a more sustainable export good and marketing tool, stimulating the interest of the Qing government's reform-oriented groups in German expertise. In the wake of the revolutionary events of 1911/12, many wealthy Chinese people relocated to Qingdao diffusing cultural binaries, but even more importantly: they experienced the city's infrastructural amenities first-hand, thus impacting positively on appropriating related knowledge and expertise. When the provisional president of the new Republic of China, Sun Yat-sen, visited the city to learn about its institutions, he apparently said: "Qingdao pleased me extraordinarily. It is the model system of a city for future China” (Naumann-Schultz 1985: 184). This statement resonates with Steinmetz's observation that colonial rule was gradually transformed into "some sort of colonial partnership" (Steinmetz 2007: 40).

\section{Fitting-The Aesthetic Casting Mold}

Yet before this vision became reality, "the German Blue Jackets [coll. for the Marines] had busily plumbed and sketched along the coast of the dirty Yellow Sea, and indeed identified some beautiful suntraps" (Stenz 1902: 48). Resonating with popular imagination of colonial environments, their vision of Qingdao seems to have been envisioned as an overseas version of the newly built marine port of Wilhelmshaven. This Northern German city was the German emperor's new North Sea harbor that grew concurrently with the navy itself, designed as a model for water works, landscape engineering, and ship building (Blackbourn 2006: 143). Both cities shared technical and architectural leaders, such as Georg Gromsch (1855-1910), a civil servant who had led planning and construction work in Germany before his overseas deployment (Warner 1996: 118). Qingdao's leading architect and survey engineer, Georg Franzius (1842-1914) also sought inspiration from Hong Kong-its "beautiful design with forest and ponds, promenades and a racing court" that he planned to imitate (ibid.: 89). For an overseas military hub, the health of soldiers was even more important. With a flawlessly designed, centralized water system-the navy's idea-poor sanitation would become an issue of the past, while at the same time addressing the challenge of tropical, often epidemic diseases (Eckart 1997: 465). ${ }^{14}$

Besides the German predilection for mastering landscapes (actually an interest they shared with the Chinese), and their hope to outshine previous foreign settlements in China, the meticulous planning of Qingdao's water supply to guarantee public health was strongly connected to experiences 
during its first year of settlement in 1898. Diphtheria, a typhoid epidemic, and other bowel infections were haunting the fledgling colony, driving up mortality rates, despite the official propaganda of a climate beneficial for European bodies. During the same year, an unexpectedly dry summer also firstly showcased the environmental limitations of Shandong province, endangering the city's drinking water supply and public hygiene. In early 1900, the Qingdao government reported that all diseases occurring at this point were problematic to every colonial settlement in its early stage of development. ${ }^{15}$ By finalizing the infrastructure, however, these issues were to be overcome, and the "epidemiological costs" that were an inherent part of colonial discourse could be kept low (Beattie 2011: 41). Yet it sounds like whistling in the dark when the 1899 report points out how flourishing Hong Kong had to fight even more severe hygienic conditions in its early days than Qingdao at that point. ${ }^{16}$

\section{(Dis)connecting-The Colonial Bodies}

The increasing number of bowel infections during summer time could be linked to Shandong's hot and humid monsoon climate, as documented in the 1899 medical report, where the overall mortality rate was three times as high than the previous year. The severity and large scale of these outbreaks were considered the result of "unfavourable sanitary conditions". ${ }^{7}$ Impoverished people from all over the province, who had pushed into the city for work, and ended up in dirty and overcrowded housing, were identified as the reason for the epidemic spreads (Zhan 2002: $47 \mathrm{f}$.). Because of their spare use of water, "pre-modern" sanitary and medical practices, most foreigners considered the locals to be unclean and unhealthy. Their stoic acceptance of epidemic lethality may have enforced prejudices. Even many Chinese people regarded migrant workers as a health and social problem. According to the memoranda, "soil contamination and thus related insufficient water supply" caused diseases, especially when combined with "inadequate living conditions". ${ }^{18}$ Such solidified prejudices silently supported relating governmental sanctions, such as demolishing all previously existing traditional housing on a wet contagious ground soil. ${ }^{19}$

Theoretically, most potential health hazards were eradicated by early 1899. Qingdao's new outline then divided the settlement into an European town (Qingdao proper), a Chinese town (Dabaodao), and a village for Chinese workers (Zhan 2002: 51). ${ }^{20}$ The center of the European town was placed south at the tip of the peninsula, the so-called "outer roads" (Außenrheede), and with the big harbor to the north on the "inner roads" (Innen- 


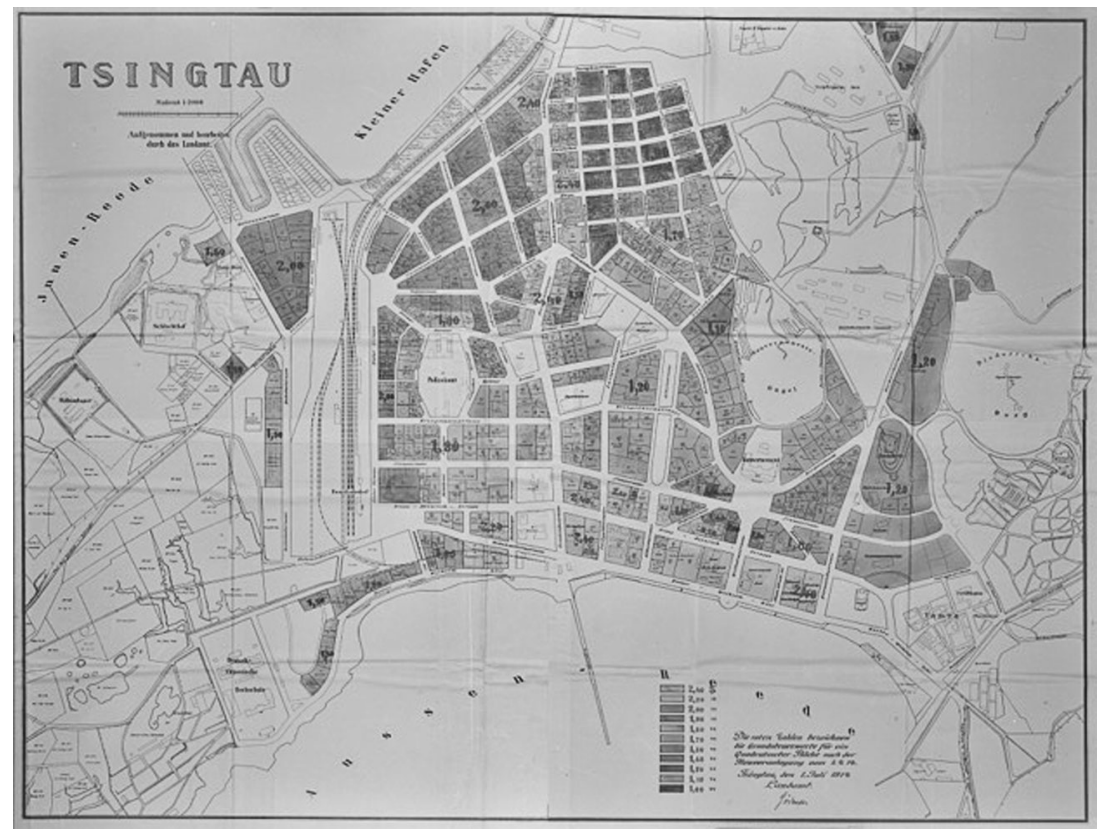

Fig. 1 Land Register Map of Qingdao Proper (http://www.tsingtau.org/kataster-kartentsingtau-1914/katasterkarte-tsingtau-zentrum)

rheede) (Fig. 1). The Chinese town of Dabaodao lay halfway in between, where its affluents would neither contaminate the European town, nor the harbor bay as the natural watershed protected both. The pathogenically most dangerous workers' villages were projected northeast and southwest of the city center (Warner 1996: 162). Even though racial and ethnic separation was a standard practice in most colonial settlements, it was harder to realize in a city that had grown naturally before foreign occupation (Osterhammel 2009), and for Qingdao's construction, the few previously existing buildings were torn down. MacFarlane's analysis of infrastructure and sanitation in colonial Bombay, for example, tells a similar story of removing Indian living quarters that were considered as dangerous and rebuilding segregated housing to mitigate infectious spreads (MacFarlane 2008: 419).

This means a social and cultural division between Europeans and Chinese was established and extended to the latter's different sociFal groups. Although colonizers were rarely among themselves, with native servants and members in the colonial enforcement, Qingdao's rigid separation of living quarters for the sake of public hygiene must be interpreted in the discourse of "subordination and superordination" (Osterhammel 2009: 287). It was a visible materialization of a "rule of difference," enforced by a segregated legal system (Steinmetz 2007: 39). The colonial administration 
commissioned construction in the European town to German firms established in Shanghai, and to individual landlords in Dabaodao. But it took responsibility for accommodating the Chinese workforce in "the village" that was crucial for the success of the whole enterprise, trying to provide new living quarters that would meet traditional style housing halfway (Warner 1996: 130). Additional building regulations addressed problems connected to overcrowding as perceived elsewhere in China. These were not only concerned with the organized removal of excrements but also prescribed a minimum room volume per person (Matzat 1985).

Such a strict segregation between European and Chinese quarters divided by the harbor, and the surrounding workers villages involved the formation of slums right from the beginning (Zhan 2002: 53) For planning the water and sanitation infrastructure, however, this spatial and social segregation had advantages. For a centralized system, the city's geographic partition yet meant to segment into three almost independent circuits. These needed to be compatible but could have different technological standards. Thus, water flows could be directed for affluents not to merge, and most importantly to not influence each other's quality. The water system itself featured three separate parts for each section: rainwater, wastewater, and sewage canals. Depending on the area and local soil condition, these could run open or underground. Once the construction pits were closed, the underground waterways remained invisible reminders of differences between the two primary groups of the population, even when individuals transgressed these boundaries.

Differences also manifested in building material: underground sewage clay pipes had a diameter of 200 centimeter, smaller cement pipes one of 50 to 75 centimeter, similar to the bricks lining open canals. ${ }^{21}$ Three categories of substances can be distinguished: wood, imported from Asia for construction aids until the Qingdao forests had grown sufficiently; bricks, burnt near the construction sites; and metal ware exclusively imported from Germany, which accounted for a huge cost factor. Lloyd shipping's regular passages secured cargo multiple times per year, a requirement the relatively small navy could not have satisfied itself. The construction order was sequenced from freshwater to rainwater to wastewater pipes. After becoming operational, the individual stretches were connected. ${ }^{22}$ Providing European living quarters with clean drinking water was the first objective. With relatively little precipitation for most of the year, run-off was merely an inconvenience, but excrements were collected in buckets by Chinese contractors and thus remained a potential health risk. ${ }^{23}$ Finalizing the core system in Qingdao proper in 1903 resulted in the jubilant official notice that no further case of typhoid fever had occurred since. ${ }^{24}$ When the fresh 


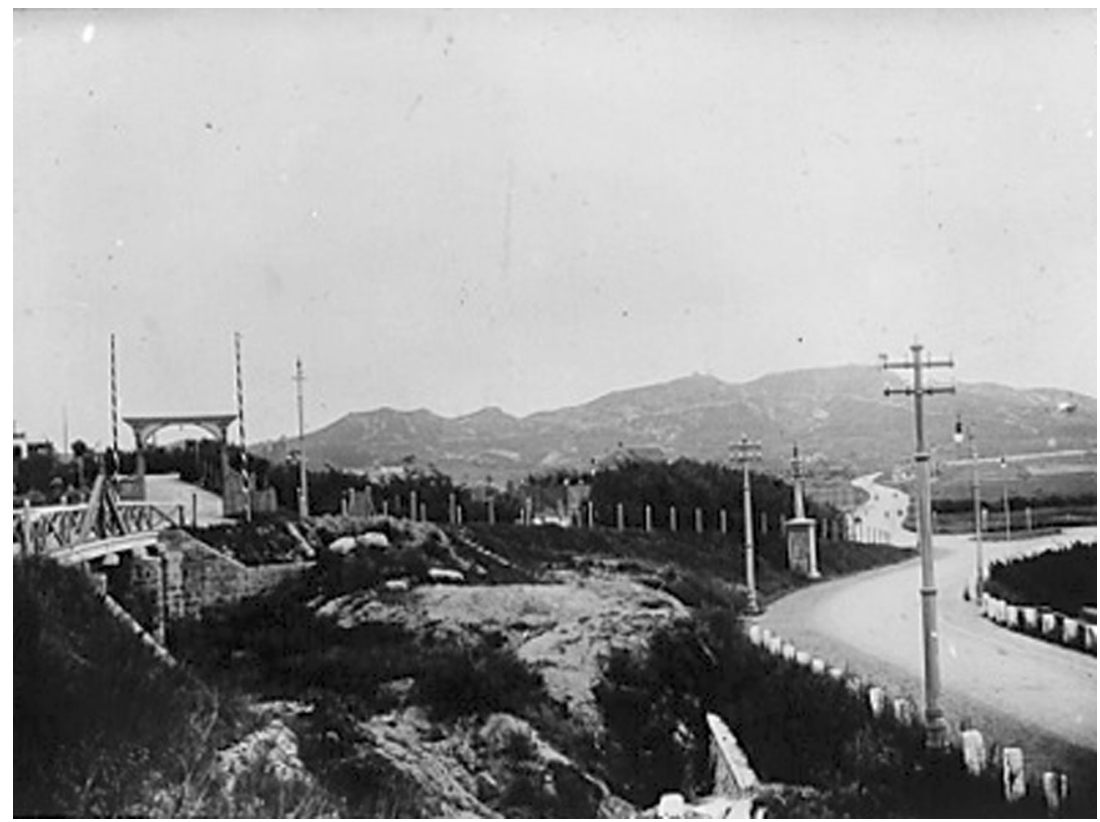

Fig. 2 "Roads and electrical lines at the Edge of Qingdao" (German Federal Military Archive, Freiburg i.Br.: BArch MSG 217197 A071)

water pipes finally reached Chinese workers' quarters five years later, they arrived with public washing places that were allegedly used "happily". 25

Although core systems were established as soon as 1903, none of the three circuits was ever finished entirely, as the pipes represented urban growth involving foundation work. All other infrastructure could be coconstructed (with minimal delay) to ensure the most convenient living standard for colonial forces, civil residents, and their visitors. Electricity, electrical and petroleum streetlights had been already operational in 1899, and successively expanded along with the road system (Fig. 2). Once Qingdao's Beach Hotel and High Altitude Camp opened in 1904, the city's successful outreach was measured in the number of summer guests. ${ }^{26}$ It was not until Japan occupied the equally nicely designed, but little fortified Russian-Chinese town of Dalian that construction in Qingdao finally slowed down. The water infrastructure then lay silently underground, but not prone to be forgotten as the vein-system still needed first-aid amends. 


\section{Digging-The Cultural Gap}

From a modern perspective, the city's technological differentiation seems motivated by at least some degree of eco-racism. Ethnic groups were exposed to environmental risks and hazards in unequal ways, based on their social and racial status (Melosi 1995). To a great extent, Qingdao's outline simply responded to the bay's topography and geology. Streets and pipes were co-constructed, and the annual reports repeatedly mention how the hard granite and basalt base interfered with implementing the highest technological standard of subterranean pipes all over. ${ }^{27}$ This favored an economic decision for the most hygienic yet cost effective solution: in Dabaodao's drainage canals were led above ground, but underground in Qingdao proper. To address these "intercultural sanitary-issues" while keeping rising costs at bay, the engineers conceptualized two independent systems that only ran together in the gulf; the settlement(s) for Chinese workers were not connected to it. ${ }^{28}$ It is undeniable that Shandong's infrastructural tabula rasa resulted in a two-class drainage system. And it is undeniable that this decision was influenced by sanitary standards being differently perceived by foreigners and locals. De facto, it resulted in a form of environmental inequality that distributed environmental risks unevenly among the city's social groups. Especially in the unplanned slums, problems of public hygiene were eminent but seldom systematically addressed (Zhan 2002). Bad public health as a result of soil conditions and geography was a universal, democratic problem of foreign settlements in China, often a result of unsuitable land that had been allocated by the Chinese local governments to foreigners on purpose (Warner 1996: 21). Eco-racism as geographical, environmental inequity thus actually worked both ways.

A deep fear of soil contamination and related epidemics persisted as a plea for Qingdao's spatial segregation, that according to medical historian Wolfgang Eckart even culminated in a "segregation hysteria" (Abgrenzungshysterie, 1997: 466). The main thorns in the government's side were insufficient Chinese hygienic practices, especially wild defecation, despite some newly constructed public toilets. ${ }^{29}$ National differences are occasionally mentioned in the government reports on sanitation, and it seems it judged workers in general, herewith merely extending the domestic attitude towards lower classes to a new group of subordinates: The people accused of bad hygienic behavior were mostly impoverished landless workers or "kulis," who executed all the construction work (that was administered by the navy, but facilitated by civil servant engineers and contracted by local international companies). In pre-revolutionary China public collection of excrements secured fertilizer for agriculture, a practice only slowly abandoned with the introduction of water closets and artificial fertilizer (Cao 
2016: 203). In Qingdao, this shift took place shortly after 1911 (Eckart 1997: 463), indeed facilitated by its infrastructural framework. It is possible that poor (landless) Chinese natives in Qingdao did not appreciate the value of their remains, did not consider that foreigners would appreciate them, or simply did not care about polluting someone else's property. The same problem had been reported in Beijing and other Chinese cities. In a sustainable practice excrement-carrying waters were additionally used to prevent streets from dusting (Rogaski 2004); a sight that certainly fostered both racial prejudices as well as environmental anxieties.

One way or another, the local soil properties made contamination a problem. Were pathogens washed into the ground water, they could trickle into unprotected wells. Before Qingdao's central water supply was finalized, these were the only sources of potable water, but none of them were protected against inflow, posing a health hazard following heavy rainfalls. ${ }^{30}$ But medical orders to use only boiled water so as to prevent the spread of bowel infections were being ignored. Eventually, contamination of public spaces became a punishable offence, and regulations enforced by the help of native facilitators. ${ }^{31}$ A drinking water-supply, declared unobjectionable and beneficial to people's health in a memorandum of 1900, was not only to be provided by a centralized pipe system, and was supposed be the colonial government's primary concern alongside wastewater canals and strict regulations for excrement collection. ${ }^{32}$ Once finished, drinking water pipes could be tapped from public fountains all over Qingdao proper and later Dabaodao. Water quality was tested every four weeks at the bacteriological station, and its results filled pages in the memoranda, accounting for its importance to the government. ${ }^{33}$

While establishing the city's drinking water supply turned out relatively easy, dealing with sewage proved much more complex. This was primarily related to the role proper sewage systems played for maintaining public health, and the fact that navy doctors were convinced that largescale earthworks contributed to the spread of diseases, especially typhus abdominalis. During Qingdao's first phase of development from 1898 to 1905 , large quantities of potentially sewage-contaminated soil were moved around town, and the soldiers and workers, who came in direct contact with pathogens, spread them around. ${ }^{34}$ Based on the perceived intimate connection between soil and water, pathogens and health, the hospital's water supply was thus designed as another semi-independent circuit within the city: an electro-powered pressure drain pipe from the closest well, with a discharge connection to the European town's water system. ${ }^{35}$ Here, the highest technological standard was not only a means of displaying technocultural superiority, but of proving the best medical care possible for deployed soldiers (Eckart 1997: 465). 


\section{Gasping-At Unintended Consequences}

Since their emergence over the last 150 years, physical metaphors have most commonly been used to underline the importance of infrastructure for settlements and civilizations (van Laak 2004: 75), as pipes and canals are the "veins" of a city. In the case of Qingdao, three continuously expanding circuits connected to the hinterland continuously pumped fresh water in and used water out of the system. But the initial shift from wells to pipes-from local to supra-local system-had made Qingdao's ecology and water supply vulnerable. The well-meant intention to improve public hygiene soon turned into boon and bane for the city. The decade following occupation noted a decline in lethal bowel infections and epidemic outbreaks, but all kinds of dysenteries remained part of everyday life as Wolfgang Eckart has described in his medical history (Eckart 1997: $465 \mathrm{f}$.). In particular, medical reports and observations from the meteorological observatory indicate correlations between summer rainfall with high temperatures and the vulnerability of the colonial body. During early and late summer, infections tended to increase. And although bowel bacteria of newcomers often needed time to adapt (ibid.), an immediate link exited to the sanitary infrastructure. 1903 is the first year reported with no typhoid fever in Qingdao; 1910 still notes the absence of infections, but they remained endemic in Shandong province. For this, the benefits of the city's rigid separation of living quarters served as an explanation. ${ }^{36}$ Still, affluents washed into the bay unfiltered along with pathogens for all kinds of diseases, exposing the limits of even "optimally" segregated water systems. Unfortunately, Qingdao's geography only allowed for limited possibilities of sewage treatment. Along the lower stretches of rivers and pipes close to the bay, for example, distances between suitable plains and connecting tubes were too long to realize irrigation fields. In turn, this lack of water treatment caused problems for the freshwater supply.

Before the construction of a centralized large-scale water supply system, the local Chinese settlements had relied on wells. Their supply, however, reacted rather sensitively to stresses on the hydrological regime. The year 1899 already experienced a drought that was apparently caused by climatic fluctuation, but intensified by an increased water use through construction works and inflowing population. Initially, brickyards located close to (Chinese) living quarters were thought causal to drying up some wells completely. ${ }^{37} \mathrm{New}$ wells needed digging and provisions made for future dry periods. By removing the old Chinese town and the resultant move of the brickyards, notably eased this tension (Zhan 2002) despite marginal rainfalls over the next years. ${ }^{38}$ Unfortunately, the sources do not allow an estimate of whether the problem of drying wells was merely relocated to 
the new workers' villages, resulting in environmental discrimination, or whether the problem disappeared naturally with a rising ground water table. ${ }^{39}$ The government considered a dammed pond, a dam, or even an aqueduct from the Laoshan Mountains as supplementary to the future central water supply. While the former two options were to form an entity with other measures to collect ground and rainwater, its high costs designated it as an emergency option. Besides, estimates from 1899 stated that one of the more basic structures would provide service and drinking water for Qingdao in sufficient quantity and quality. ${ }^{40}$

The fresh water demand of a population growing by several thousands rather than hundreds of Chinese and Europeans rapidly overstrained the brand-new infrastructure connected to the old wells. In 1904, a new drinking water plant from the Licun River was projected together with a new pumping station. ${ }^{41}$ The official 1907 headcount notes 1,484 civilian Europeans (and Americans under the same category), 161 Japanese and 9 Indians in addition to 31,569 Chinese. ${ }^{42}$ Together, they consumed an annual total of 394,197 cubicmeter water (23 per cent more than in 1906) through a pipe network of 46,889 meter (about 25 per cent longer than in 1906), facilitated by both stable and provisional pressure tubes (about 25 per cent). By 1910, Qingdao's fresh water supply needed backing from dams and embankments further up Laoshan, as the growth of population did not slow down. ${ }^{43}$ By this time, its water infrastructure had become a sophisticated network of river and waterside wells that could be regulated in synchrony with each other in response to dry periods, heavy rainfall or flooding. ${ }^{44}$ Drinking water supply for the Chinese population, especially the workers, remained insufficient; and their sewage pipes were not connected until 1908. ${ }^{45}$ Before Chinese houses were connected to the central water pipes, inhabitants had to supply themselves from "water stations", that is, a fresh water distribution system similar to that of old Chinese cities. An example of environmental injustice or even racism based on the unequal access to clean environmental resources. In response to acknowledged weak spots in sewage treatment, protective constructions were implemented around coastal wells, whose water quality was tested more often during the rainy season when overflowing was more frequent. ${ }^{46}$

Since the beginning of its urbanization, Qingdao had undergone several stages to enlarge its infrastructural capacities. Starting from a few hundred Europeans and Chinese, the age-old attractions of urban settlements, like work opportunities or better living conditions, had increased its population to approximately 5,000 Europeans and 30,000 Chinese inhabitants within the first decade. In response to such a demand, both land development and infrastructural planning had been amended several times within the first five years, and the government paid attention to extending its sophis- 
ticated pipe system accordingly. These measures, however, only addressed issues in Qingdao proper and Dabaodao, but excluded the workers' towns and villages where about 20,000 of the 53,312 Chinese inhabitants lived in 1913 (Zhan 2002: 51); and they were still insufficient to solve all waterrelated problems. Alongside the residential areas where brick production remained a bottomless pit for water consumption, Qingdao's industry had become demanding, and public water works were already unable to meet that demand in $1905 .{ }^{47}$ With the finalization of infrastructure supporting the core of the colony and connecting it to the hinterland, it had transformed the city into a busy marketplace by 1907 (Mühlhahn 2013: 120).

1903 had also seen the opening of a brewery and a mineral water factory. Germania Brew would strain the water supply by pumping massive amounts of its natural resource base from farther, fresher wells into town. ${ }^{48}$ Iltis Mineral Water also pumped directly from the area's southern wells that were fed underground from mountain springs and trickle water (Warner 1996: 154). In the initial development plan, the navy's engineers and architects had designated locations for commercial plants to areas where heavy water consumption would not interfere with the supply for the population. And in addition they projected at least semi-independent circuits connected to the main water-supply system. Given the unexpected growth, however, a total amount of 587,000 cubicmeter was pumped into the city in 1910, signifying an increase of 3.16 per cent compared to the year before; involuntarily sabotaging the meticulous planning. ${ }^{49}$

\section{Draining-The Natural Resources}

To meet environmental challenges, deriving from transforming parts of China into a Germanized cultural landscape, a development task of utmost importance and difficulty was afforestation (Rollins 1997). Initially, forestry seemed a corrective to alleged Chinese mismanagement as reflected in "deforested" hillsides: ${ }^{50}$ The mountain ranges around the city were soon called "Qingdaoer Schweiz"-in romantic tradition embracing the colonial territory as an extended part of Heimat. But it was forests and not barren peaks that the German hearts were longing for. Techno-enthusiasts from Europe were disappointed to find such dried-out lands in a culture that had been widely admired for its hydro-engineering (Wittfogel 1957). Forest works, the 1900s memorandum points out, were commanded to prevent soil erosion and thus prevent the future harbor and roadsteads from silting up; and to protect the agricultural character of Qingdao's surrounding landscape; but first and foremost to improve the city's water supply. ${ }^{51}$ 


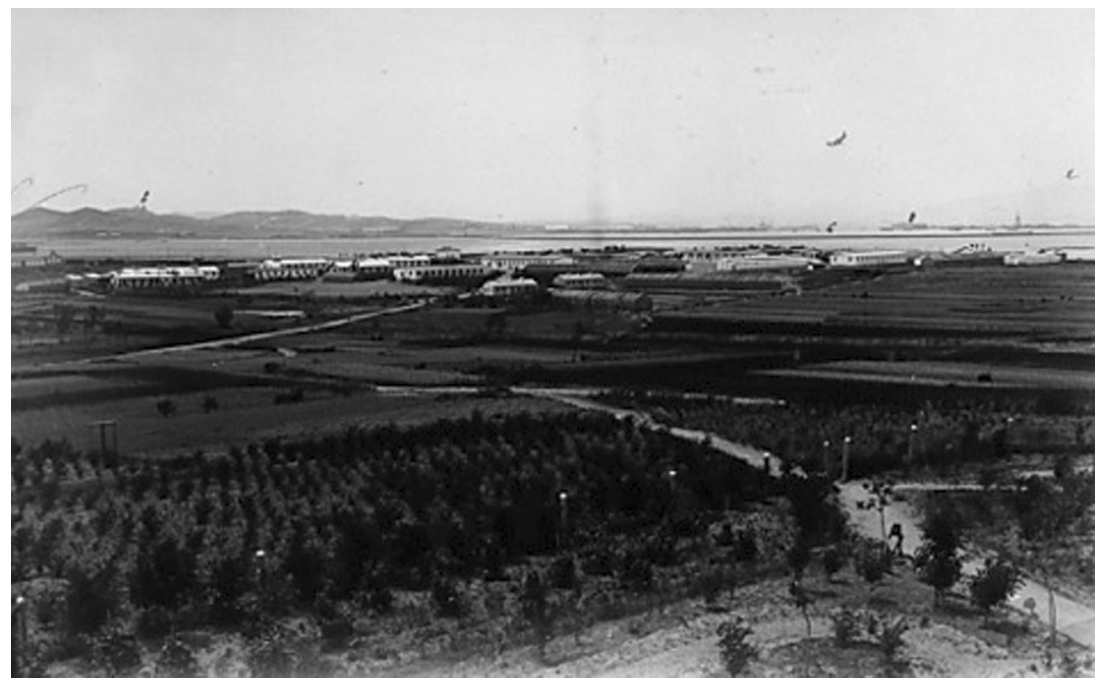

Fig. 3 "View on Forest Park and Fields Around Qingdao" (German Federal Military Archive, Freiburg i.Br.: BArch MSG 217197 A107)

The necessary large-scale constructions were justified by their gradual economic and fiscal importance, and the colonial forestry department received additional personnel as early as $1900 .{ }^{52}$ A raised groundwater table would turn larger areas (especially alongside the riverbeds) into arable lands, and thus provide support for the impoverished parts of the Chinese population, turning them into potential customers for German and other foreign goods. A substantial tree-cover would further liberate the colony from expensive timber imports into an arid region and "the situation of timber trade in the Silent Ocean" that was dominated by Japan. ${ }^{53}$ The area chosen to become the green heart of the colony started out with 500 squaremeter along the east and south side of the hills lining up along the coast. This location was supposed to maximize water catchment (during the annual rainy season) and enhance the bay's aesthetic appeal (especially upon entering it). And although the Han-Chinese expansion had caused blanket deforestation for economic and cultural reasons almost everywhere (Elvin 2004: 35), the treeless mountaintops in Shandong had to be attributed to other geological and geographical reasons (Qingdao Soil 1997).

From the perspective of German engineers and foresters, the whole region seemed in need of ecological and hydrological improvement. No plant life could be detected right along the mountain springs, a drawback that was rectified beginning as soon as 1900 by covering the bare soil and 
sand with "horizontal tiles of grass". ${ }^{4}$ These were supported by two-year old pine trees further down the bare slopes in the following year, whose roots were further expected to break the hard and rocky sediments into fertile ones..$^{55}$ Rubble obstructions throughout the mountains had already been constructed before the summer rainfall of the first year of occupation, to catch silt and rainwater. Instead of freely flowing down the valleys and empty riverbeds, more water was forced to trickle away on the spot, thus leveraging the "moisture line" and contributing to soil generation. At the same time its filtering qualities were enhanced; in combination with so called "plant holes" along the slopes, the forest engineers estimated a foundation for new top soil to develop within five years. ${ }^{56}$ But increasing water supply through afforestation had inadvertent consequences, supporting Wolfgang Reinhard's argument that colonial development and politics were driven more by happenstance than by actual planning (Reinhard 1996: 5).

In Qingdao, many of these consequences derived from a multi-level strain imposed by the city's infrastructure. Besides pulling considerable amounts of water in support of the human population, the non-human population consumed as well. Apparently, the first years of settlement were so dry that reports felt the need to inform its stakeholders that the young forest plantations had survived without watering during the rainy season of 1904. Before that, even trees in outdoor cultivations had apparently required watering. With the forest cover arrived yet another, albeit not unwelcome guest: an extensive grass cover that also needed water. ${ }^{57}$ But although young trees and fresh grass already added some green color to the bay area, this was still unsatisfactory for a model city. Thus halfgrown acacias and poplars were imported from China and Japan to line the boulevards. As roads and pipes began sprawling through the area, they were accompanied by trees: willows and alders at the riverbanks and around the contributory pipes, and later the railway lines as well. ${ }^{58}$ Thus the water veins were turned into green veins, but this required extensive watering to root. Their monetary value made them green jewels consisting of forced inlays into the landscape. Although the greening of pipes was supposed to enhance hydrological capacity around these veins, the choice of particularly water-hungry species illustrates the limited ecological and climatological understanding at the time.

Though Qingdao's climate differed significantly from the tropics, its landscape was modeled after that region Hong Kong. As Qingdao's development planner emphasized, that city was lush and green, full of gardens with exotic plants. In its "civilized" state it disclosed nature's wealth in an almost jungle-like fashion, resonating perfectly with the contemporary imagination of colonial environments (Zantop 1997). Although German foresters certainly realized the climatic limitations of a mainly arid region 
like Shandong, they firmly believed in the power of water engineering. To identify the most suitable plants to realize their green vision, a "forest park" modeled after the British botanical gardens followed suit. Promoted as a comparably more economical and natural way of "German" landscape conservation (Lind 1998: 29) and in conjunction with its use as recreational space for walking and horseback riding, it can be described as a colonial form of the (also British-inspired) landscape garden that influenced German approaches to engineered nature (Rollins 1997: 37). Experimental cultivations grafted domestic and foreign species, exposed others artificially to unfamiliar (climatic) conditions, and grew seedlings for local use and export (ibid.: 29). Much like the British example, this park was also to support the imperial economy in the Carlowitzian sense of sustainable forestry by identifying species that would not only please foreign aesthetics but also be of economic benefit. Therefore, trees would be used to green the city and its infrastructural network; support the local ecology; provide wood for construction, railroads, and mining companies; and serve as an article of exportation for the Qing Empire. ${ }^{59}$

Based on the fame and prominence of German (scientific) forestry, and given the almost simultaneous implementation of pipes and trees in Qingdao, it is safe to assume that greenery soon turned into a natural feature of modern water infrastructure. The general acceptance of German infrastructural technology can be interpreted as a form of cultural appropriation (Ferguson \& Gupta 1997: 5) that encompassed landscape alteration as both a design element as well as a natural tech-enhancement. For the Germans, on the other hand, the accompanying trees and forest park were a means to feel at home (Groeneveld 2016: 71). A reflexive appropriation of Western water technology only became possible under the relative political stabilization in China after the revolutionary events in 1911. From this point onwards, the administration realized that colonial rights were to be given back successively and that neighboring Japan was about to extend its influence to the continent. Infrastructure as an export commodity still provided possibilities for future economic and cultural exchange between Germany and China, but with limited funds on the former's side. In similar foresight, not only medical but also educational and vocational institutions had been established in Qingdao. These included professional schools and colleges, whose curricula were designed to train workers in the construction and maintenance of German style infrastructure as well as forestry. ${ }^{60}$ With the ongoing reform/modernization process during the late Qing dynasty, those workers and engineers were in high demand throughout the country. 


\section{Reporting-The Outcome}

Although not extended to the city as a whole, the struggle for public hygiene and establishing a sophisticated (and still intact) water infrastructure certainly counts as one of the larger and positive achievements during Germany's engagement in China. Yet it also created a severe ecological imbalance. After one decade of extensive development, water security in Qingdao could be broken down to two areas: quality versus supply. Technology had brought germs more or less under control, but water shortages during the summer months had become a regular feature, despite increasing precipitation during the annual rainy seasons. ${ }^{61}$ The latter was manifested, for example, in flooding the underdeveloped Chinese parts of the settlement, calling for an extension of the rainwater canalization in $1905,{ }^{62}$ funded with financial resources originally earmarked for the European part of town and the railway. The initially mentioned water shortage in the summer was due to the settlement's natural growth and the concurring sophistication of its water-consuming industry, but also related to the tractive forces of intensified agriculture and young vegetation.

From the perspective of environmental history, the story of colonial water infrastructure in Qingdao is one of increasingly complex ecological relations within the Jiaozhou Bay area. Major factors were pipes and trees, both used without considering their impact on the local ecology (a concept already under development) and the fragile local hydrology. In its material outline, the colonial water infrastructure first and foremost reflected the city's spatial division, mirroring the quality and scale of underground works and street/pipe-side planting. Bolstered by practices of personal and public hygiene, this geographical separation contributed to intercultural problems and scientific racism towards the Chinese inhabitants of the protectorate's territory. It corresponded to the prevailing negative attitude towards members of the working class in general and the Chinese working class in particular at that time, and raised questions of environmental and ecological justice that are worth further investigation. In line with the European domestic discourse, water infrastructure became moreover crucial in establishing public hygiene. In practice, however, this policy merely applied to Qingdao proper and the parts inhabited by Europeans and Chinese merchants. In reality effects on public hygiene remained limited due to the city's systematic social and cultural segregation created by its invisible, underground two-tier system. The colonial town's hierarchical standard of infrastructure predicts today's definition of poverty that is closely tied to the accessibility of infrastructure (van Laak 2004: 12). Population numbers quickly outgrew infrastructural development, thus mirroring the problems of slum dwelling in all major European cities of the time. 
Nonetheless Qingdao, thirdly, showcases its role model qualities for challenging issues such as urbanization and, related, public hygiene in China that were part of reform ideas addressing poverty reduction and modern living standards. Wealthy Chinese, who moved to Qingdao after 1911, enjoyed its amenities and were willing to advocate German infrastructural standards elsewhere. A young generation of graduates from Qingdao's schools, technically trained in German water, forestry, and education systems enjoyed an excellent reputation for their knowledge and expertise, served as ambassadors for this cause. Fourthly, representing an exported metaphorical "tool of knowledge" (Biener 2001: 15-17), infrastructural technology thus contributed to an increasing appreciation of technological amenities and European sanitary values within the framework of a comprehensive educational infrastructure.

Yet the requirements of a water infrastructure system and its maintenance posed after all an enormous pressure on the region's natural environment. A negative feedback loop within the hydrological system of Greater Qingdao followed the high demands of water by the city and its hinterland. Techno-cultural and environmental factors increased needs: a growing population as well as an industry with increasing standards of public hygiene on the one hand and intensified agriculture with an extensive young vegetation cover on the other. Resulting water shortages and demand for infrastructural extension had been notable since 1899. A lacking (outspoken) awareness of hydrological engineering by means of pipes and trees was consequential to both zeitgeist and the ambivalent Western idea of ecological sacrifices to modernization. Efforts in afforestation were hence rather increased than reconsidered, and-in affirmation of Wolfgang Reinhard's observation that happenstance eventually drives colonial politics-the same applied for the city's three-partite water system. Qingdao as a city built from scratch offers a point of departure for a comprehensive study of colonial forestry and water politics that are intertwined by their ecological relation.

Within this process that co-created an ecologically novel hydroscape (as a subcategory of landscape that is characterized by its water flows), Qingdao's outgrowing colonial water infrastructure bears similarities to the "developmental epidemics" it was supposed to prevent. The confined systems of middle and upper-class Qingdao were secured against epidemics at the socio-ecological cost of the working class and induced long-term ecological transformations that still affect the greater Jiaozhou Bay area to this day. But its theoretical nature as provision for a convenient and healthy daily life speaks a different language. Within the framework of a techno-cultural mission in the Far East, infrastructure obtained the role of a "tool of knowledge" that created knowledge spaces to establish a future 
inter-cultural dialogue. A lot of environmental casualties lined the path of technological innovation and education in both countries. Thus, Qingdao, model city, is also exemplary for the gap between planning at the drawing board and the geographical reality of large-scale water projects as well as for the dangers of transplanting potentially invasive species into alien environments.

"Drink more water!" is a common recommendation among Chinese people for solving any problem. High water intake is supposed to guarantee moisture, while washing out harmful contaminants, also on a metaphorical level. Water keeps people healthy, and thus today public water dispensers can be found in abundance in public spaces. They are the technological equivalent to water vendors walking the streets of imperial China, accessible to everyone free of charge. There is also an awareness of "climate" and "environment" affecting human health, and well-being that is closely linked to the possibility of simply being in the wrong "place" if drinking water does not serve as remedy. Qingdao drank, and drank, and drank. At first sight, this has made it healthy-but under the scrutiny of a macro-perspective, its ecological health was poor. On a different level, the case of Qingdao's water infrastructure tells a hybrid story of technology's unwanted side-effects in history (Hård \& Jamison 2005: 13) and allows a glimpse at the long-term effects of ecological stresses caused by nineteenth-century imperialism-in this case the traces of water abstraction within sediments and groundwater table. Especially during the first half of the twentieth century, Qingdao was shaken by a quick succession of regimes imposed by the Japanese forces and the intermediary Chinese governments, between 1914 and the formal establishment of the People's Republic of China in 1949. All of them made use of the infrastructural amenities established by the Germans, but neither of them wanted or had the financial capacities to maintain and expand them. Nonetheless, the colonial water infrastructure displayed an astonishing resilience. It only failed once many decades post-installation, and according to urban legend, when repair workers descended into the canal system, they found spare parts strategically placed by thoughtful German engineers. Today, the sprawling conurbation has long swallowed the former mining sites and border areas into its boundaries. Within the old citycenter, however, the former European town, the German water infrastructure is still in place and functional. And the surrounding lush green hills rising behind bright beaches have turned Qingdao into a prime holiday location. 


\section{Endnotes}

1 The term goes back to Chinese research in the 1920s and 1930s arguing for a diversification of approaches to colonialism, building on a 1916 publication by Lenin, who argues for a two-step model in establishing colonial rule (Mühlhahn 2013: 107; including annotations 15 and 16$)$.

2 Urban metabolism has been taken up by environmental history following William Cronon's work on Chicago. It shows a distinct focus on contexts of industrialization, see for example: Joel Tarr 2002. The Metabolism of the Industrial City: The Case of Pittsburgh. Journal of Urban History (28): 511-545; Christopher Kennedy et al. 2007. The Changing Metabolism of Cities. Journal of Industrial Ecology (11): 43-59. This includes the analysis of hard scientific data to describe the exchange between the city and its hinterland, as done, for example, by Sabine Barles 2005. L'invention des déchets urbains. France: 1790-1970, Seyssel: Champ Vallon; Sabine Barles 2005. A Metabolic Approach to the City: Nineteenth and Twentieth Century Paris. In: Dieter Schott et al. (eds.). Resources of the City: Contributions to an Environmental History of Modern Europe, Aldershot: Ashgate: 28-47. Within German research the concept has been taken up by Rolf Peter Sieferle et al. 2006. Das Ende der Fläche. Zum gesellschaftlichen Stoffwechsel der Industrialisierung. Wien/Köln: Böhlau. For Asia, see for instance Stephen Boyden et al. 1981. The Ecology of a City and its People: The Case of Hong Kong. Canberra: Australian National University Press.

3 German Federal Military Archive, Freiburg i.Br.: BArch RM3 6797: 55.

4 BArch RM3 6693: 247-335 and BArch N253/54: 25.

5 BArch RM3 6796: 272.

6 BArch RM3 6796: 2721.

7 Qingdao Municipal Archive (QMA) B0001/007/00010/0133.

8 QMA B0001/007/00010/0055.

9 BArch RM3 6800: 131r.

10 BArch RM3 6800: 1311.

11 BArch RM3 6796: 2721.

12 BArch RM3 6797: 70.

13 BArch N 22480.

14. BArch RM3 6797: 68.

15 BArch RM3 6796: 269r.

16 BArch RM3 6796: 269r.

17 BArch RM3 6796: 2681.

18 BArch RM3 6796: 2681.

19 BArch RM3 6796: 268r.

20 Zhang explains the composition and geographical arrangement of two emerging hut villages that accommodated the Chinese workers, who were driven by common push and pull factors of urbanization: $47-51$. These villages were soon to turn into slums and extended into the hinterland of Qingdao, integrating many small villages and settlements. After ten years the population would amount to more than 20,000 people. As these slums were in the same state of infrastructural development, a partition in three is sufficient for this paper.

21 QMA B0001/001/00162/0058.

22 QMA B0001/001/00162/0057.

23 BArch RM3 6808. 
24 BArch RM 6806: 1361.

25 BArch RM3 6817: 66r.

26 BArch RM3 6806: 137r.

27 BArch RM3 6797: 270r.

28 BArch RM3 6797: 701.; BArch RM3 6796: 270r and QMA B0001/001/00113/0010.

29 BArch RM3 6796: 268.

30 BArch RM3 6796: 268r.

31 BArch RM3 6796: 2681.

32 BArch RM3 6796: 268r.

33 RM3 6817: 661-67r.

34 BArch RM3 6796: 268-271.

35 BArch RM3 6796: 2691.

36 BArch RM3 6806: 1361 and BArch RM3 6917: 59.

37 BArch RM3 6796: 2731.

38 BArch RM3 6817: 60.

39 BArch RM3 6796: 2731.

40 RM3 6796: 2731.

41 BArch RM3 6802: 1391.

42 BArch RM3 7127: 24.

43 BArch RM3 6817: 66r.

44 BArch RM3 6817: 671.

45 BArch RM3 7127: 33.

46 BArch RM3 6817: 611.

47 BArch RM3 6808: 128.

48 An environmental historical study of the long-term ecological impacts of the Qingdao brewery is currently being researched by Shen Hou from Renmin University under the tentative title "The Tonic of Nature: An Environmental History of Tsingtao Beer."

49 RM3 6796: 269r and RM3 6817: 60.

50 In fact, most of China had been deforested during the Han expansion, as Mark Elvin vividly describes in his Retreat of the Elephants (2004). Yet it is unclear how far back German foresters dated these events.

51 BArch RM3 6796: 269r.

52 BArch RM3 6797: 272r.

53 BArch RM3 6797: 272r-273l; to this day Qingdao remains the main Chinese port for timber imports from the EU and other places.

54. BArch RM3 6797: 71.

55 BArch RM3 6799: 215.

56 BArch RM3 6797: 272r.

57 BArch RM3 6800: 1401; BArch RM3 6808: 128 and BArch RM3 6808: 130.

58 BArch RM3 7128.

59 BArch RM3 6808: 130.

60 BArch N224 62: 3; RM3 6797: 20.

61 BArch RM3 6804.

62 BArch fRM3 6808: 128. 


\section{References}

Albertini, Rudolf von 1982. Europäische Kolonialherrschaft. Die Expansion in Übersee von 1880-1914. München: Heyne.

Allen-Emerson, Michelle et al. (eds.) 2012. Sanitary Reform in Victorian Britain, Part I, London; Vermont: Pickering \& Chatto.

Arnold, David 2013. Everyday Technology. Machines and the Making of India's Modernity. Chicago: University of Chicago Press.

Baige, Xia 1998. Ein jahrtausendealtes System zerbricht: Chinas Reform- und Modernisierungsbemühungen und der Untergang des Kaiserreiches. In: Hans-Martin Hinz and Christoph Lind (eds.). Qingdao. Ein Kapitel deutscher Kolonialgeschichte in China, 1897-1914. Berlin: Deutsches Historisches Museum. URL: http://www.dhm.de/archiv/ ausstellungen/tsingtau/katalog/auf1_17.htm (last accessed: 11.10.2016).

Beattie, James 2011. Empire and Environmental Anxiety: Health, Science, Art and Conservation in South Asia and Australasia, 1800-1920. Basingstoke: Palgrave Macmillan.

Bennett, Brett and Joseph Hodge (eds.) 2011. Science and Empire: Knowledge and Networks of Science Across the British Empire, 1800-1970. Basingstoke: Palgrave Macmillan.

Biener, Anette 2001. Das Deutsche Pachtgebiet in Qingdao in Shandong 1897-1914. Institutioneller Wandel durch Kolonialisierung. Bonn: Matzat.

Blackbourn, David 2006. The Conquest of Nature. Water, Landscape, and the Making of Modern Germany. New York: Norton.

Cao, Mu 2016. The Public Lavatory of Tianjin. A Change of Urban Faeces Disposal in the Process of Modernisation. Global Environment (9): 196-218.

Conrad, Sebastian 2013. Rethinking German Colonialism in a Global Age. The Journal of Imperial and Commonwealth History (41): 543-566.

Cronon, William 1992. Nature's Metropolis. Chicago and the Great West. New York: Norton.

Eckart, Wolfgang 1997. Medizin und Kolonialimperialismus. Deutschland 1884-1945. Paderborn: Schöningh.

Elvin, Mark 2004. The Retreat of the Elephants. An Environmental History of China. New Haven: Yale University Press.

Ersten, Maurits 2016. A Matter of Relationships-Actor Networks of Colonial Rule in the Gezira Irrigation System, Sudan. Water Alternatives (9): 203-221.

Ferguson, James and Akhil Gupta 1997. Culture, Power, Place: Explorations in Critical Anthropology. Durham: Duke University Press.

Gandy, Matthew 2004. Rethinking Urban Metabolism: Water, Space, and the Modern City. City (8): 363-379.

Groeneveld, Sabina 2016. Far Away from Home in Qingdao (1897-1914). German Studies Review (39): 65-79.

Headrick, Daniel 1981. The Tools of Empire. Technology and European Imperialism in the Nineteenth Century. New York: Oxford University Press.

Herold, Heiko 2006. Deutsche Kolonial- und Wirtschaftspolitik in China 1840-1914. Unter besonderer Berücksichtigung der Marinekolonie in Kiaotschou. Köln: Ozeanverlag Herold.

Hård, Mikael and Andrew Jamison 2005. Hybris and Hybrids. A Cultural History of Technology and Science. New York: Routledge.

Hinz, Hans-Martin and Christoph Lind (eds.) 1998. Tsingtao. Ein Kapitel deutscher Kolonialgeschichte in China, 1897-1914. Berlin: Deutsches Historisches Museum.

Laak, Dirk van 2004. Imperiale Infrastruktur. Deutsche Planungen für eine Erschließung Afrikas 1880-1960. Paderborn: Schöningh.

Leutner, Mechthild 1997. "Musterkolonie Kiaotschou". Die Expansion des Deutschen Reiches in China. Deutsch-chinesische Beziehungen 1897-1914. Eine Quellensammlung. Berlin: Akademie.

Leutner, Mechthild 2009. "Sind wir doch ehrlich, so haben wir uns doch alle als armselige Blechgötzen erkannt..." Elisabeth von Heykings ambivalente Positionen zur Kolonialpolitik. In: Marianne Bechhaus-Gerst and Mechthild Leutner (eds.). Frauen in den deutschen Kolonien. Berlin: Links: 56-66. 
Leutner, Mechthild and Klaus Mühlhahn 1994. Die "Musterkolonie” - Die Perzeption des Schutzgebietes Jiaozhou in Deutschland. In: Kuo Heng-yü and Mechthild Leutner (eds.). Deutschland und China: Beiträge des Zweiten Internationalen Symposiums zur Geschichte deutsch-chinesicher Beziehungen. Berliner China-Studien, 21. München: Minvera: 339-423.

Lind, Christoph 1998: Die architektonische Gestaltung der Stadt Tsingtau während der deutschen Kolonialzeit. PhD Thesis, TU Berlin.

MacFarlane, Colin 2008. Governing the Contaminated City. Infrastructure and Sanitation in Colonial and Post-Colonial Bombay. International Journal of Urban and Regional Research (32): 415-435.

Matzat, Wilhelm 1985. Die Tsingtauer Landordung des Chinesenkommissars Wilhelm Schrameier. Bonn: Matzat.

Melosi, Martin 1995. Equity, Eco-Racism, and Environmental History. Environmental History Review (19): 1-16.

Mühlhahn, Klaus 1998. Deutsche Vorposten im Hinterland: Die infrastrukturelle Durchdringung der Provinz Shandong. In: Heinz-Martin Hinz and Christoph Lind (eds.). Qingdao. Ein Kapitel deutscher Kolonialgeschichte in China, 1897-1914. Berlin: Deutsches Historisches Museum: 146-158.

Mühlhahn, Klaus 2000. Herrschaft und Widerstand in der "Musterkolonie" Kiaotschou. München: Oldenbourg.

Mühlhahn, Klaus 2009. Prostitution in der "Musterkolonie" Kiaotschou. In: Marianne Bechhaus-Gerst and Mechthild Leutner (eds.). Frauen in den deutschen Kolonien. Berlin: Ch. Links: 96-101.

Mühlhahn, Klaus 2013. Mapping Colonial Space. The Planning and Building of Qingdao by German Colonial Authorities, 1897-1914. In: Laura Victoir and Victor Zatsepine (eds.). Harbin to Hanoi. The Colonial Built Environment in Asia, 1840 to 1940. Hongkong: Hongkong University Press: 103-150.

Naumann-Schultz, Joachim 1985. Unter Kaisers Flagge. Deutschlands Schutzgebiete im Pazifik und in China einst und heute. München: Universitas.

Osterhammel, Jürgen 2009. The Transformation of the World. A Global History of the Nineteenth Century. Princeton, NJ: Princeton University Press.

Penck, Albrecht 1911. Qingdao. Berlin: Mittler und Sohn.

《青岛市志-自然地理志/气象志》第四篇《土壤》, 北京 : 新华出版社, 1997年。(Natural Geography and Meteorology of Qingdao. Volume 4 "Soil," Beijing: Xinhua Press, 1997).

Pritchard, Sara and Thomas Zeller 2010. The Nature of Industrialization. In: Martin Reuss und Stephen Cutcliffe (eds.). The Illusory Boundary. Environment and Technology in History. Charlottesville: University of Virginia Press: 69-100.

Reinhard, Wolfgang 1996. Kleine Geschichte des Kolonialismus. Stuttgart: Kröner.

Richthofen, Ferdinand 1897. Kiaotschou. Seine Weltstellung und voraussichtliche Bedeutung. Berlin: Stilke.

Robinson, Ronald 1991. Introduction. In: Clarence Davis and Kenneth Wilburn (eds.). Railway Imperialism. New York: Greenwood.

Rogaski, Ruth 2004. Hygienic Modernity. Meanings of Health and Disease in Treaty-Port China. Berkeley: University of California Press.

Rollins, William 1997. A Greener Vision of Home. Cultural Politics and Environmental Reform in the German Heimatschutz Movement, 1904-1918. Ann Arbor: University of Michigan Press.

Rollins, William 1999. Imperial Shades of Green: Conservation and Environmental Chauvinism in the German Colonial Project. German Studies Review (22): 187-213.

Schmidt, Vera 1979. Die deutsche Eisenbahnpolitik in Shantung, 1897-1914. Ein Beitrag zur Geschichte des deutschen Imperialismus in China. Wiesbaden: Harrassowitz.

Schnee, Heinrich 1920. Deutsches Koloniallexikon 1920 (Buchstabe: Kiaotschou). URL: http://www.ub.bildarchiv-dkg.uni-frankfurt.de/Bildprojekt/Lexikon/php/suche_db. php?suchname=Kiautschou (last accessed: 07.06.2015).

Scott, James C. 1998. Seeing like a State. How Certain Schemes to Improve Human Condition Have Failed. New Haven: Yale University Press.

Steinmetz, Georg 2007. The Devil's Handwriting: Precoloniality and the German Colonial State in Qingdao, Samoa, and Southwest Africa. Chicago: Chicago University Press. 
Stenz, Georg-Maria 1902. In der Heimat des Konfuzius: Skizzen, Bilder und Erlebnisse aus Shandong. Steyl: Missionsdruckerei.

Tirpitz, Alfred von 1919. Erinnerungen. Leipzig: Koehler.

Vögele, Jörg and Hideharu Umehara 2015. Public Health in Qindao (Tsingtau) in the Early 20th Century Under Three Different-German, Japanese and Chinese-Rules: The Qingdao Hospitals. In: Dies. (eds.). Gateways of Disease. Public Health in European and Asian Port Cities at the Birth of the Modern World in the Late 19th and Early 20th Century. Göttingen: Cuveilliers: 61-75.

Wang Wei, Zhou Shangzhe, Li Bingyuan, Xie Bo and Feng Xiaozhen. 2011. 㻤山冰臼之质疑 (Queries About the Glacial Potholes of Mountain Laoshan, China). 第四纪研究 (Quarterly Sciences) (31): 917-932.

Warner, Torsten 1996: Die Planung und Entwicklung der deutschen Stadtgründung Qingdao (Tsingtau) in China: Der Umgang mit dem Fremden. PhD Thesis, University of Hamburg.

Weber, Heike 2012. Urbanisierung und Umwelt: Ein Plädoyer für den Blick auf Materialitäten, Ressourcen und urbane „Metabolismen“. Informationen zur modernen Stadtgeschichte: $28-34$.

Wittfogel, Karl 1957. Oriental Despotism. New Haven: Yale University Press.

Worster, Donald 1986. A Dream of Water. Montana: The Magazine of Western History (60): $72-74$.

Zantop, Susanne 1997. Colonial Fantasies: Conquest, Family, and Nation in Precolonial Germany 1770-1870. Durham: Duke University Press.

Zhan, Erpeng 2002. Entstehung, Wandlung und Sanierung der „Hüttenviertel“ in Qingdao (Tsingtau): Siedlungsbau und Veränderung der Stadtstruktur als soziales Problem in den Küstenstädten der VR China. Berlin: Logos.

Agnes Kneitz

Department of History

Renmin University of China

59 Zhongguancun Ave

100872, Beijing

China

a.kneitz@ruc.edu.cn 